Katarzyna GRATA ${ }^{1}$

\title{
DETERMINING CELLULOLYTIC ACTIVITY OF MICROORGANISMS
}

\begin{abstract}
Decomposition of cellulose to glucose requires complex cooperation of glycoside hydrolase enzymes. As a result of glycoside $\beta-1,4$ bonds hydrolysis, shorter chains of cellulose, oligodextrin, cellobiose and glucose are created. A number of bacteria and fungi demonstrate the capacity to degrade cellulose. Their activity can be assessed with the use of qualitative and quantitative methods. Qualitative methods with the use of e.g. Congo red, are used in screening studies, however, they do not provide information about the quantity of the produced enzyme. Spectrophotometric methods are more accurate and they measure the quantities of reducing sugars with the use of appropriate substrates, e.g. carboxymethylcellulose is used to determine endoglucanases, avicel cellulose to determine exoglucanases and Whatman filter paper to determine total cellulolytic activity. Activity of microorganisms depends not only on their species or type but also, among others, on substratum composition, cultivation conditions and the appropriate selection of parameters of the carried out enzymatic reactions.
\end{abstract}

Keywords: cellulolytic enzymes, cellulolytic microorganisms, cellulolytic activity, determination methods

\section{Introduction}

Cellulose, which is part of the lignocellulosic biomass, is a common and easily accessible polymer in natural environment. It is an organic compound, which is the main component of plant cell walls. It creates the most resistant and stable skeleton built from cellulose fibrils, so called microfibrils and macrofibrils. Hydrogen bonds occurring between the neighbouring hydroxyl groups and Van der Waals forces ensure stabilisation of cellulose fibres and the required conformation of glucose particles. Its content in plants depends on their age, plant type and parts. For example it is $45-50 \%$ in leafy stems, $40-55 \%$ in woody stems and $15-20 \%$ in leaves [1-4].

Cellulose is a non-branched polysaccharide built from several hundred to several thousand D-glucose groups, connected by $\beta-1,4$ glycoside bonds. Cellobiose is the basic unit in the cellulose chain. A cellulose chain has a reducing and non reducing end Cellulose fibres contain areas with ordered structure and parallel microfibrils, so called crystalline regions and the areas with loose microfibrils, so called amorphous regions. Additionally, they may contain various irregularities, e.g. twisted microfibrils, micropores or empty spaces. These different areas occur alternately. The complex structure of cellulose and the percentage content of crystalline and amorphous areas have a major impact on the properties of the polymer. The increase of the content of crystalline areas in cellulose

\footnotetext{
${ }^{1}$ Institute of Environmental Engineering and Biotechnology, University of Opole, ul. kard. B. Kominka 6, 45-035 Opole, Poland, phone +48 7740160 56, email: kgrata@uni.opole.pl
} 
increases rigidity of cellulose fibres and their resistance to chemical and enzymatic decomposition [1, 2, 4-7].

\section{Cellulolytic microorganisms}

As the main source of carbon generated by photosynthesis, cellulose is a nutrient for cellulolytic microorganisms using lignocellulosic biomass. Cellulose decomposition undergoes through hydrolysis of $\beta-1,4$ glycoside bonds. However, due to stabilisation of cellulose microfibres with these bonds, cooperation of several enzymes is required for effective decomposition. Cellulose is mineralised by cellulolytic microorganisms belonging to various groups: fungi, aerobic and anaerobic bacteria $[4,6,8,9]$.

Each group of microorganisms uses different methods for cellulose decomposition. Thanks to generation of mycelium hyphae, fungi can permeate through capillaries and pores in lignocellulose, exposing cellulose directly to the generated and supplied enzymes. Fungi with the capacity of cellulose hydrolysis are presented in Table 1.

Table 1

List of most efficient cellulose degrading fungi

\begin{tabular}{|c|c|c|}
\hline Type of fungi & Microbial strains & References \\
\hline Aspergillus & A. niger, A. fumigatus, A. flavus, A. hortai, A. terreus, A. oryzae & {$[4,8,10-14]$} \\
\hline Penicillium & P. brazilianium, P. purpurogenum, P. chrysogenum & {$[8,15]$} \\
\hline Mucor & Mucor sp. & {$[11]$} \\
\hline Rhizopus & Rhizopus sp. & {$[12]$} \\
\hline Trichoderma & T. reesei, T. harzianum, T. viride & {$[2,8,10,13,16-18]$} \\
\hline Fusarium & F. solani, F. oxysporum & {$[8,13]$} \\
\hline
\end{tabular}

Aerobic bacteria usually release free cellulolytic extracellular enzymes. They can also be present on cell surface in the form of enzymatic complexes, increasing the efficiency of hydrolysis. In the case of anaerobic bacteria, cellulose decomposition is carried out by a system of complex enzymes, occurring in the form of a protrusion of a cell wall, so called cellulosomes. Their structure resembles a fist, which opens upon contact with cellulose $[4,19,20]$. The most active producers of $\beta-1,4$-glucanases are aerobic and anaerobic bacteria, among others: Cellulomonas, Cytophaga, Micromonospora, Bacillus, Clostridium (Table 2).

Table 2

List of most efficient cellulose degrading bacteria

\begin{tabular}{|c|c|c|}
\hline Type of bacteria & Microbial strains & References \\
\hline Bacillus & $\begin{array}{c}\text { B. pumilus } \text { EB3, B. subtilis, Bacillus } \text { sp. Y3, Bacillus sp. RK3, } \\
\text { Bacillus } \mathrm{sp} \text {. AR03, Bacillus licheniformis KIBGE-IB2, } \\
\text { Bacillus cereus, } \text { B. mojavensis, Bacillus } \text { BS-2 }\end{array}$ & {$[3,8,15,21-25]$} \\
\hline Paenibacillus & P. terrae, P. cellulose & {$[8,26]$} \\
\hline Cellulomonas & Cellulomonas uda, C. thermocellum, Cellulomonas sp. ASN2, \\
Cellulomonas sp. & {$[8,27,28]$} \\
\hline Cellulomvorans & Cellulomvorans sp. & {$[8]$} \\
\hline Burkholderia & Burkholderia sp., B. cepacia & {$[26]$} \\
\hline Pseudomonas & Pseudomonas sp., Pseudomonas sp. MN34 & {$[8,15,26]$} \\
\hline
\end{tabular}

Cellulolytic microorganisms produce a number of complementary enzymes, despite the fact that cellulose decomposition requires breaking one bond [9]. 


\section{Cellulolytic enzymes}

Cellulolytic enzymes can be divided into three groups, taking into consideration their structure, enzymatic activity, specificity and active centres. Cellulolytic enzymes are made of so called domains - catalytic and binding carbohydrates (CBM, Cellulose Binding Module) and have a characteristic shape active point, which determines their activity. CMB domain influences binding with cellulose surface and is located on the C-terminus of enzyme, connected with the catalytic domain at $\mathrm{N}$-terminus. These enzymes (endoglucanases and exoglucanases) act in a complex way, resulting in shortening of cellulose chain, single units of cellobiose and glucose. $\beta$-glucosidase is part of cellulolytic enzymes complex. The enzyme does not attack cellulose but it decomposes cellobiose and reduces its blocking activity towards cellobiohydrolase and endoglucanase (Fig. 1; Table 3) $[2,5-8,14,22,29]$.

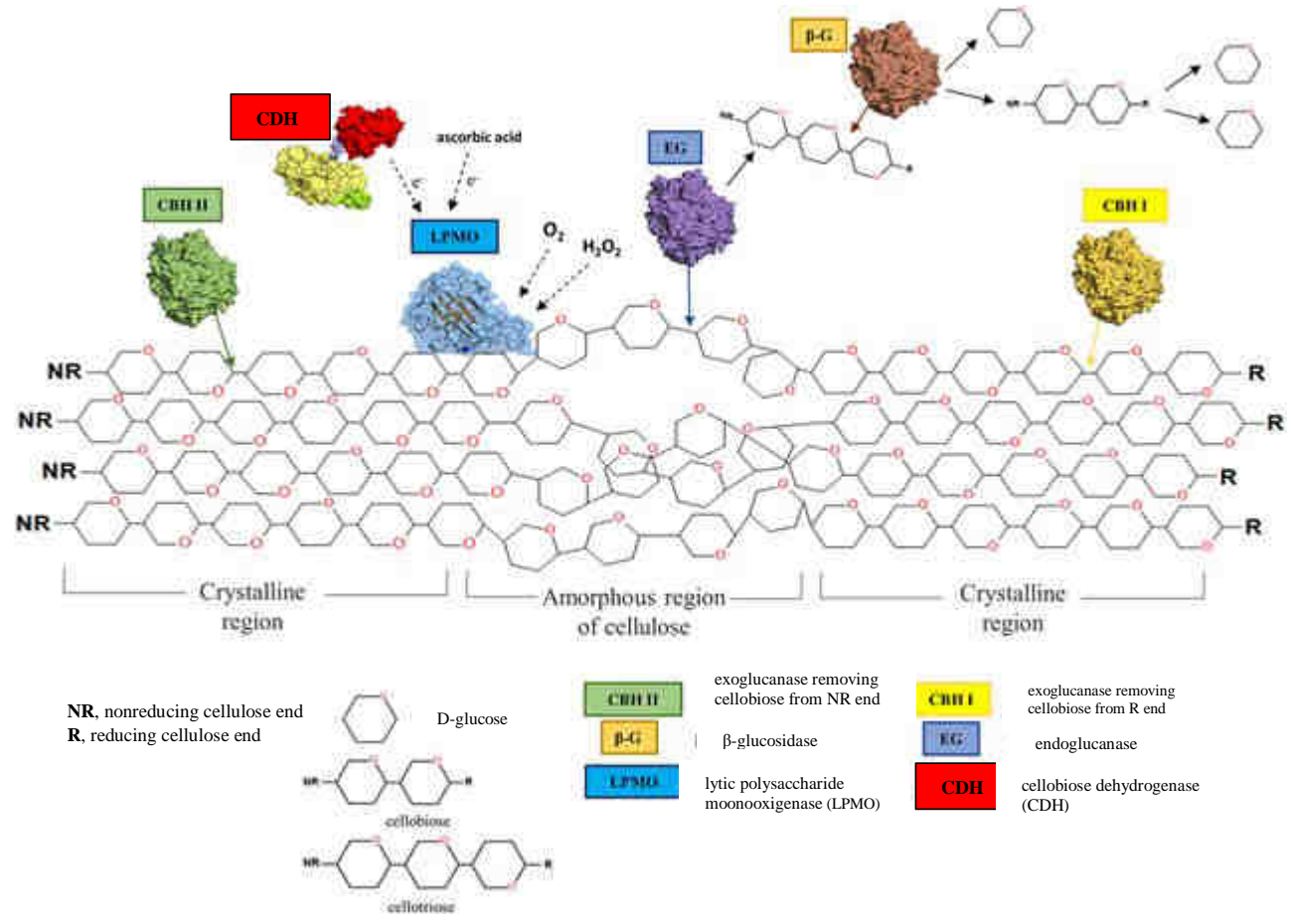

Fig. 1. Model of enzymatic cellulose degrading [30]

Synthesis and activity level of cellulolytic enzymes depend on the presence of inhibitors and inductors as well as other physical and chemical parameters. Cellulose with appropriate structure, low content of lignin and susceptible to the influence of enzymes or the presence of substrates, among others carboxymethylcellulose (CMC), hay, bran and marc, is a very good biological inductor of microbiological cellulases. The products of cellulose hydrolysis are most often inhibitors of cellulases. Cellobiose inhibits activity of endoglucanases and exoglucanases, whereas the presence of glucose may repress the activity of $\beta$-glucosidase. Other compounds, among others solvents, phenol compounds and 
surfactants can also be inactivators. It is a characteristic quality not just for a microorganism type or species but a strain. Cellulases generated by various microorganisms usually differ in the optimum conditions for their highest activity. Simultaneously, these conditions may considerably differ from the optimum conditions of growth and development $[27,32,34]$.

Characteristics of cellulolytic enzymes [2, 5, 6, 8, 24, 31-33]

Table 3

\begin{tabular}{|c|c|}
\hline Enzymes & Enzymes characteristics and activity mechanism \\
\hline $\begin{array}{c}\text { Endoglucanase (cellulase), } \\
\text { endo-1,4- } \beta \text {-D-glucanase, } \\
\text { CMCase } \\
\text { (EC 3.2.1.4) }\end{array}$ & $\begin{array}{c}\text { A deep crack, which can hold a cellulose chain, is enzyme active centre. } \\
\text { Carboxymethylcellulose may be the substrate. } \\
\text { They decompose long cellulose chains in the internal, amorphous part of } \\
\text { cellulose. } \\
\text { Oligosaccharides (soluble celodextrins) and insoluble fragments of cellulose } \\
\text { are created. }\end{array}$ \\
\hline $\begin{array}{c}\text { Exoglucanase, } \\
\text { glucan-1,4- } \beta \text {-glucosidase } \\
\text { (EC 3.2.1.74) } \\
\text { Exo-1,4- } \beta \text {-D-glucanase } \\
\text { (cellobiohydrolase I - CBI, } \\
\text { cellobiohydrolase II - CBII) } \\
\text { (EC 3.2.1.91) } \\
\end{array}$ & $\begin{array}{c}\text { The enzyme active centre is a widened loop, which creates a tunnel for one of } \\
\text { the hydrolised ends of cellulose chain. } \\
\text { They act at external parts of crystalline cellulose. } \\
\text { Shorter chains of oligosaccharides are generated. } \\
\text { They release single units of cellobiose or glucose as the main product. } \\
\text { Cellobiohydrolases I act on non reducing chain end. } \\
\text { Cellobiohydrolases II act on reducing chain end. }\end{array}$ \\
\hline $\begin{array}{c}\beta \text {-glucosidase, } \\
\beta \text {-glucoside hydrolase, } \\
\text { (cellobiose) } \\
\text { (EC } 3.2 .1 .21 \text { ) }\end{array}$ & $\begin{array}{l}\text { They do not have the carbohydrates binding module. } \\
\text { Their active centre is in the form of a pocket. } \\
\text { They are frequently bound to the cell surface of cellulolytic organisms and } \\
\text { they are present in cytoplasm of anaerobic bacteria. } \\
\text { They act on oligodextrins (cellodextrins) and cellobiose, releasing glucose } \\
\text { particles prior or during transport to a cell interior. } \\
\text { They remove glucose particles from non reducing ends. }\end{array}$ \\
\hline
\end{tabular}

The most frequently used quantitative and qualitative methods for determining cellulolytic activity of microorganisms will be described below.

\section{Methods for determining cellulolytic activity of microorganisms}

There are cultivation and spectrophotometric methods using various substrates, relevant for determining activities of individual enzymes.

Supernatants are most frequently the source of enzymes in the research, obtained from bacteria or fungi cultures carried out in optimum growth conditions for each microorganism, centrifuged at 5000-12000 rpm for 10-20 min at temperature $4{ }^{\circ} \mathrm{C}[22,24$, $26,27]$.

\section{Cultivation methods}

Cultivation methods are part of quantitative methods group, which do not provide information on the quantity of the generated enzyme. They are commonly regarded as the best methods to identify potential producers of cellulase enzymes and determine their cellulolytic activity. Solid mediums containing the appropriate substrate can be used in these studies in assessing the activity of microorganisms or their supernatants' colonies activity. The most frequently used is carboxymethylcellulose (CMC) or sodium carboxymethylcellulose $(\mathrm{CMC}-\mathrm{Na})$ in concentration from 0.1 to $1.0 \%$. Media may 
additionally contain other ingredients, among others yeast extract, peptone, mineral salts (Table 4) [21, 26].

Table 4

Examples of media for the cultivation of cellulolytic microorganisms

\begin{tabular}{|c|c|}
\hline Composition of the medium & Reference \\
\hline $\begin{array}{c}\text { CMC-agar }\left[\mathrm{g} / \mathrm{dm}^{3}\right] \text { for bacteria: } \mathrm{KH}_{2} \mathrm{PO}_{4} 1.0 ; \mathrm{MgSO}_{4} \cdot 7 \mathrm{H}_{2} \mathrm{O} 0.5 ; \mathrm{NaCl} \mathrm{0.5;} \mathrm{FeSO}_{4} \cdot 7 \mathrm{H}_{2} \mathrm{O} 0.01 ; \\
\mathrm{MnSO}_{4} \cdot \mathrm{H}_{2} \mathrm{O} 0.01 ; \mathrm{NH}_{4} \mathrm{NO}_{3} 0.3 ; \mathrm{CMC}_{10.0} \text { Agar } 12.0 ; \mathrm{pH}=7.0 \text { (plate stained with a Congo } \\
\text { red) }\end{array}$ & [21] \\
\hline $\begin{array}{c}\text { CMC-agar }\left[\mathrm{g} / \mathrm{dm}^{3}\right] \text { for bacteria: }\left(\mathrm{NH}_{4}\right)_{2} \mathrm{SO}_{4} 0.5 ; \mathrm{KH}_{2} \mathrm{PO}_{4} 10.0 ; \mathrm{K}_{2} \mathrm{HPO}_{4} 5.0 ; \mathrm{MgSO}_{4} 0,1 ; \mathrm{NaCl} \\
0.2 ; \text { yeast extract } 10.0 ; \mathrm{CMC} 3.0 \text { (plate stained with a Congo red) }\end{array}$ & {$[22]$} \\
\hline $\begin{array}{c}\text { CMC-agar [\%] for bacteria: } \mathrm{NaNO}_{3} 0,2 ; \mathrm{K}_{2} \mathrm{HPO}_{4} 0.1 ; \mathrm{MgSO}_{4} 0.05 ; \mathrm{KCl} 0.05 ; \mathrm{CMC}-\mathrm{Na} 0.2 ; \\
\text { pepton 0.02; agar } 1.7 \text { (plate stained with a Congo red or Gram's iodine) }\end{array}$ & {$[15,35]$} \\
\hline CMC-agar for fungi [\%]: water agar 1.6, CMC $1.0 ;$ kanamycin $\left(50 \mu \mathrm{g} / \mathrm{cm}^{3}\right)$ & [36] \\
\hline
\end{tabular}

Study material in the form of cultures, fungal spores or supernatant obtained after centrifuging a microorganism culture, is pooled on the medium surface or inserted into wells cut in the medium with a cork borer. Cultivations are incubated for a definite time, depending on the origin of the biological material: bacteria at $30{ }^{\circ} \mathrm{C}$ for $48 \mathrm{~h} \mathrm{[27],} 37{ }^{\circ} \mathrm{C}$ for $24 \mathrm{~h}$ [24] and fungi at $28{ }^{\circ} \mathrm{C}$ for $48 \mathrm{~h} \mathrm{[11],25-30}{ }^{\circ} \mathrm{C}$ for 5-7 days [37]. Cellulolytic activity can be measured in time intervals, e.g. after 24, 48, $72 \mathrm{~h}$, etc. After incubation, various substances are added to the medium, in order to visualise hydrolysis zones of the substrate present in the medium. The solution of Congo red in the concentration from $0.1 \%[16,24$, $38]$ to $1.0 \%[3,11,27,37]$ is most frequently used. The dye is left for 15 min $[3,11,24$, 27], the excess is removed and the medium is next covered with $1 \mathrm{M}$ solution of $\mathrm{NaCl}$ for 15-20 $\min [3,10,15,21,37]$. The medium can also be inundated with iodine solution for 5 [39] -10 min [15, 35] or trypan blue [40]. Diffusion of CMCase enzyme to the medium decomposing CMC substrate results in generation of the substrate hydrolysis zones. After a definite incubation time and appropriate dyeing, in each case the diameters of hydrolysis zones are measured in two perpendicular lines. The measure of cellulolytic activity is the calculated cellulolytic index, $C I[21,41]$ :

$$
C I=\frac{\text { diametr of zone }- \text { diametr of bacterial colony (well) }}{\text { diametr of bacterial colony (well) }}
$$

In the case of cellulolytic activity assessment of a fungi colony, enzymatic index, EI may be calculated, which is the ratio of a hydrolysis zone to a diameter of a colony [42]:

$$
E I=\frac{\text { diametr of dyhrolysis zone }}{\text { diametr of fungal colony }}
$$

These methods are not sensitive enough and do not provide information on the quantity of the generated enzyme. They can be used in preliminary studies on the detection and definition of cellulolytic activity. Therefore, quantitative methods based on the measurement of the generated quantities of reducing sugars are most frequently used for the purpose of determining cellulolytic activity.

\section{Spectrophotometric methods with the use of DNS reagent}

Spectrophotometric methods focus on determining cellulolytic activity based on the quantity of the generated reducing sugars. Appropriate substrates are used, depending on the enzyme, which is determined. Carboxymethylcellulose (CMC), CMC sodium salt or 
amorphous cellulose are used in measuring activity of endoglucanase. Avicel cellulose is used in determining activity of exoglucanase [40, 43]. In order to assess total activity of cellulose (FPase), Whatman filtration paper is used and in assessment of cellobiose $\rho$-nitropfenyl- $\beta$-D-glucopyranoside [44].

\section{Endoglucanase activity - determining CMCase activity}

The most frequently used method is the one prepared by Miller in 1959 [44], using 3.5-dinitrosalicylic acid (DNS), which is often modified by researchers. In literature, the study procedure is the same, however, the method may differ with regard to the quantity and type of the used buffer $(0.05 \mathrm{M}$ sodium citrate, $\mathrm{pH}=4.8 ; 0.1 \mathrm{M}$ sodium acetate $\mathrm{pH}=5.0)$, substrate concentration CMC (0.5-2.0\%), quantity of the used DNS reagent, quantity of the biological material used in reaction mixture $\left(0.2-1.0 \mathrm{~cm}^{3}\right)$ and incubation conditions: temperature $\left(30-50{ }^{\circ} \mathrm{C}\right)$ and reaction time $(10-30 \mathrm{~min})[12,14,21,23,26,32$, 45]. The following description presents the modified method, which is used to determine activity of endoglucanase generated by bacteria. Three samples are prepared in the method with DNS reagent: control sample, actual sample and reagent sample, which is measured by spectrophotometry. In the control sample, $0.25 \mathrm{~cm}^{3}$ of $1 \%$ carboxymethylcellulose prepared in the buffer of $0.05 \mathrm{M}$ sodium citrate $\mathrm{pH}=4.8$ is placed in a test tube and incubated at temp. $50{ }^{\circ} \mathrm{C}$ for $30 \mathrm{~min}$. First $1.5 \mathrm{~cm}^{3}$ of DNS reagent and next $0.25 \mathrm{~cm}^{3}$ of supernatante are added after incubation. The reaction mixture is heated in water bath at temperature $100{ }^{\circ} \mathrm{C}$ for $10 \mathrm{~min}$ and next cooled down. A similar procedure applies to the actual sample, however, supernatante is added to CMC solution before adding DNS. All is incubated at temp. $50{ }^{\circ} \mathrm{C}$ for $30 \mathrm{~min}$ and further steps are the same as in the control sample. Next, both for control and actual samples, $8.0 \mathrm{~cm}^{3}$ of sterile $\mathrm{H}_{2} \mathrm{O}$ is added and absorbance is measured at wavelength of $540 \mathrm{~nm}$. The generated reducing sugars (glucose, oligosaccharides) cause transformation of DNS to 3-amino, 5-nitrosalicylic acid, which causes the change of colour from yellow to orange-red, depending on the quantity of the generated reducing sugars (Fig. 2) [46].

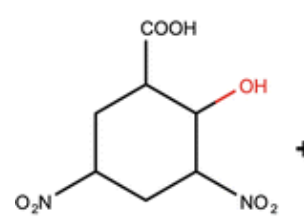

3,5-dinitrosalicylic acid

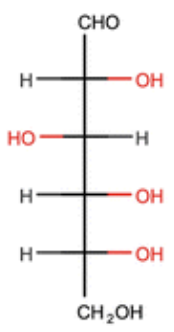

glucose

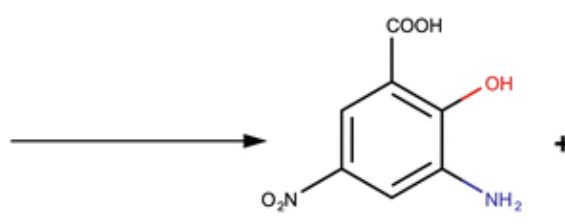

3-amino, 5-nitrosalicylic acid

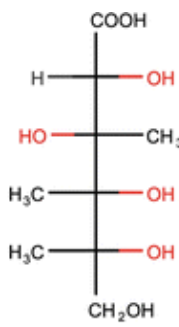

gluconic acid

Fig. 2. DNS reaction for glucose detection and quantification [47]

A standard curve, with glucose as the model, $\left(1.0\right.$ or $\left.0.5 \mathrm{mg} / \mathrm{cm}^{3}\right)$ is prepared, in order to determine activity. Figure 3 presents a model curve for glucose $\left(1.0 \mathrm{mg} / \mathrm{cm}^{3}\right)$. 


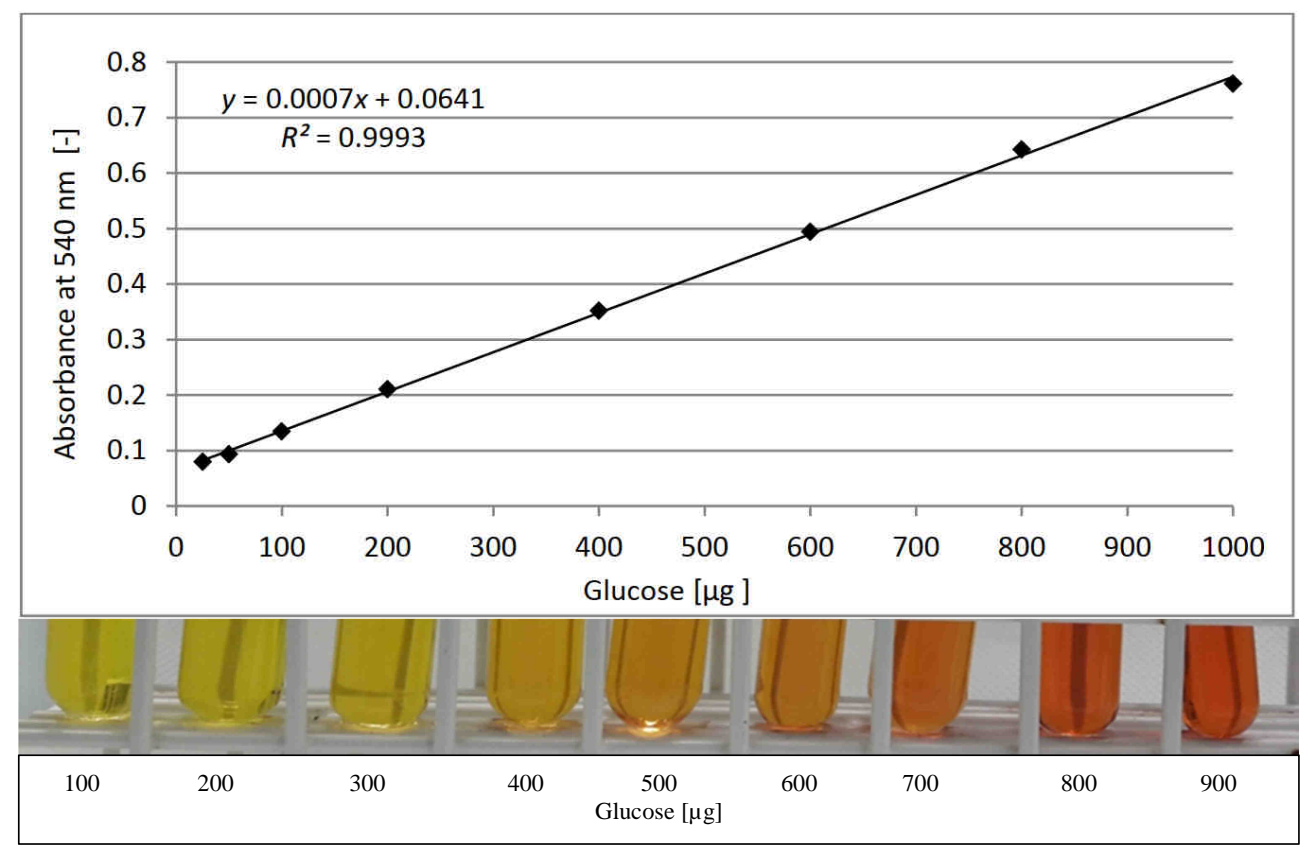

Fig. 3. Glucose standard curve for DNS test

The following formula may be used to calculate cellulolytic activity, Act [48]:

$$
\text { Act }=\frac{W \cdot 1000}{V \cdot t \cdot \mathrm{M}}
$$

where: $W$ - the amount of released glucose equivalents, $M$ - the molecular weight of the glucose, $V$ - the volume of the measured sample, $t$ - the reaction time.

After determining the amount of reducing sugars, the CMCase activity is determined and expressed in units (IU). One unit of enzymatic activity corresponds to the amount of enzyme required to liberate $1.0 \mu \mathrm{mol}$ of glucose per $1 \mathrm{~min}$ under the test conditions [23].

\section{Exoglucanase activity - determining Avicelase activity}

Exoglucanase activity is assessed by using microcrystalline cellulose (Avicel PH101) as a substrate $[26,35,39,40]$. The method involves incubation of $0.5 \mathrm{~cm}^{3}$ of the enzyme with $0.5 \mathrm{~cm}^{3} 1.0 \%$ of Avicel cellulose in $0.05 \mathrm{M}$ buffer Tis- $\mathrm{HCl}, \mathrm{pH}=8.5$ at temp. $70{ }^{\circ} \mathrm{C}$ for $10 \mathrm{~min}$ [39]. The measurement of activity according to Kim [40] and Ray [43] is based on preparation of a reaction mixture consisting of $0.5 \mathrm{~cm}^{3}$ enzyme, $1.0 \mathrm{~g}$ Avicel and $1.5 \mathrm{~cm}^{3} 0.1 \mathrm{M}$ sodium citrate buffer, $\mathrm{pH}=5.0$, which is incubated for $60 \mathrm{~min}$ at temp. $50{ }^{\circ} \mathrm{C}$. After that, it is centrifuged for $5 \mathrm{~min}$ at $10000 \mathrm{rpm}$ and $1.0 \mathrm{~cm}^{3}$ of supernatante is sampled. Both procedures assess quantity of reducing sugars by DNS method, as in the case of assessment of endoglucanase activity. Avicelase activity is defined as the quantity of enzyme, which releases $1 \mu \mathrm{mol}$ of reducing sugars during $1 \mathrm{~min}$, in the conditions of the experiment [43]. 


\section{Total cellulolytic activity of microorganisms - determining FPase activity}

Another method of cellulolytic activity assessment is determining of FPase, so called total cellulolytic activity. Similarly to assessment of CMCase activity, volumes of individual components of the reaction mixture $\left(\mathrm{cm}^{3}\right.$ of enzyme, buffer, DNS, $\left.\mathrm{H}_{2} \mathrm{O}\right)$ and reaction time may slightly differ [10, 16, 21, 26, 34, 49].

The substrate in this method is a strip of Whatman filtration paper no. $1(1.0 \cdot 6.0 \mathrm{~cm})$ with $50 \mathrm{mg}$ mass. The actual sample contains a rolled paper slip, $1.0 \mathrm{~cm}^{3} 0.05 \mathrm{M}$ sodium citrate buffer $\mathrm{pH}=4.8$ (or $0.05 \mathrm{M}$ acetate buffer $\mathrm{pH}=4.8$ ). All components are pre-incubated for $5 \mathrm{~min}$, next $0.5 \mathrm{~cm}^{3}$ of supernatante is added and all is incubated for $60 \mathrm{~min}$ at temp. $50{ }^{\circ} \mathrm{C}$. In order to stop the reaction, $3.0 \mathrm{~cm}^{3}$ of DNS reagent are added and all is heated in water bath at temp. $100{ }^{\circ} \mathrm{C}$ for 5-10 min. After cooling the reaction mixture, $20 \mathrm{~cm}^{3}$ of sterile $\mathrm{H}_{2} \mathrm{O}$ is added, test tube content is mixed and spectrophotometric measurement of the reagent sample is carried out with wavelength of $540 \mathrm{~nm}$. A control sample is prepared in the same way as the actual sample, however, supernatant is introduced after addition of DNS reagent [2, 12, 17, 22, 45].

On the basis of the standard curve, in which glucose $\left(1.0 \mathrm{mg} / \mathrm{cm}^{3}\right)$ is the medium, the quantity of the generated glucose $[\mu \mathrm{g}]$ during the reaction is determined. The value of the control sample should be deducted from the value of the actual sample. The value of FPase is expressed by $\mu \mathrm{g}$ of reducing sugars by $1.0 \mathrm{~cm}^{3}$ of the enzyme solution or in international units (IU $=\mu \mathrm{M} / \mathrm{cm}^{3} / 1 \mathrm{~min}$ ) [27].

Activity of FPase can also be determined by microplate method, using 96-well titration plates (MFPA - microplate filter paper assay) [17, 41]. $0.032 \mathrm{~cm}^{3}$ supernatante, filtration paper disc with diameter $7 \mathrm{~mm}$ and $0.064 \mathrm{~cm}^{3} 0.05 \mathrm{M}$ of sodium citrate buffer $\mathrm{pH}=4.8$ are inserted into wells. After incubation for $60 \mathrm{~min}$ at temp. $50{ }^{\circ} \mathrm{C}, 0.050 \mathrm{~cm}^{3}$ of reaction mixture is transferred to a new 96-well titration plate with previously introduced $0.1 \mathrm{~cm}^{3}$ of DNS reagent. All is incubated at temp. $95{ }^{\circ} \mathrm{C}$ for $5-10 \mathrm{~min}$. After that period, $0.036 \mathrm{~cm}^{3}$ of the mixture is transferred to a new plate containing $0.16 \mathrm{~cm}^{3} \mathrm{H}_{2} \mathrm{O}$ in each well. Absorbance is measured at $540 \mathrm{~nm}$ wavelength. FPase activity, FPU, can be calculated with the use of the following formula [17]:

$$
F P U=\left(\frac{A_{540} \text { sample }}{A_{540} / \mathrm{mg} \text { standard }}\right)(5.55 \mu \mathrm{mole} / \mathrm{mg}) \cdot\left(\frac{1}{60 \min }\right)\left(\frac{1}{X}\right)
$$

where: $A_{540}$ sample - the absorbance obtained from DNS assay for each cellulose assay, $A_{540} / \mathrm{mg}$ standard - the absorbance for $1 \mathrm{mg}$ of glucose as derived from the glucose standard curve, $5.55 \mu \mathrm{mole} / \mathrm{mg}$ - the number $\mu$ moles of glucose in $1 \mathrm{mg}, 60 \mathrm{~min}$ - the assay incubation time, $X$ - the volume of suitably diluted cellulose that is assayed $\left[\mathrm{cm}^{3}\right]$ (in the standard and $96 \mathrm{~mm}^{3}$ FPA assays is $0.5 \mathrm{~cm}^{3}$ and $0.032 \mathrm{~cm}^{3}$, respectively).

\section{Determining activity of $\beta$-glucosidase by spectrophotometric method}

$\rho$-nitropfenyl- $\beta$-D-glucopiranoside (pNPG) is used as a medium in this method and $\rho$-nitrophenol is released in consequence of hydrolysis. Reaction mixture containing $0.5 \mathrm{~cm}^{3}$ pNPG $\left(1 \mathrm{mg} / \mathrm{cm}^{3}\right), 0.5 \mathrm{~cm}^{3} 0.05 \mathrm{M}$ sodium acetate buffer $\mathrm{pH}=5.0$ was incubated at temp. $50{ }^{\circ} \mathrm{C}$ for 1 hour. Enzymatic reaction was terminated by adding $2.0 \mathrm{~cm}^{3} 1 \mathrm{M} \mathrm{Na}_{2} \mathrm{CO}_{3}$, absorbance was measured at wavelength of $400 \mathrm{~nm}$. Activity unit of $\beta$-glucosidase was defined as the quantity of enzyme, which released $1 \mu \mathrm{mol}$ of 
para-nitrophenol during one minute [40]. In this method, incubation can take $30 \mathrm{~min}$ and the medium solution concentration and volume may vary [21, 32, 35, 50]. Cellulolytic activity of microorganisms depends on their type but may also be a species characteristics. The influence of such factors as, among others, inoculum density of microorganisms, source of carbon and nitrogen, metal ions, age of culture, $\mathrm{pH}$ and temperature is also emphasised in all carried out studies [10, 14, 16, 21-24]. Therefore it is important to properly select the composition of medium and microorganisms cultivation conditions as well as the selection of parameters of the carried out enzymatic reactions.

\section{Conclusion}

Cellulose as the main source of carbon is decomposed by the enzymes which hydrolyse $\beta-1,4$ glicosyde bonds. The ability to synthesis cellulases is shown by both bacteria, among others Bacillus, Cellulomonas, Pseudomonas, and fungi Aspergillus, Trichoderma, Penicillium. In order to isolate potential producers of cellulases and initial assessment of their activity, cultivation method with the use of Congo red dye can be applied. However, the information on the quantity of generated enzyme cannot be obtained. Therefore, so called spectrophotometric methods should be used, based on the measurement of the quantity of the generated reducing sugars in the presence of DNS reagent. The activity of endoglucanases, exoglucanases and total cellulolytic activity can be determined. These procedures have been precisely defined, however, they may differ by, among others, buffer type, medium type and concentration as well as the process conditions. Therefore the process parameters should be properly selected, in order to obtain the maximum cellulolytic activity of the studied microorganisms.

\section{References}

[1] Poszytek K. Mikrobiologiczna utylizacja celulozy (Microbial cellulose utilization). Post Mikrobiol. 2016;55:2:132-46. Available from: http://pm.microbiology.pl/web/archiwum/vol5522016132.pdf.

[2] Eveleigh DE, Mandels M, Andreotti R, Roche Ch. Measurement of saccharifying cellulase. Biotechnol Biofuels. 2009;2:21. DOI: 10.1186/1754-6834-2-21.

[3] Reddy KV, Vijayalashmi T, Ranjit P, Raju MN. Characterization of some efficient cellulase producing bacteria isolated from pulp and paper mill effluent contaminated soil. Braz Arch Biol Technol. 2017;60:e17160226. DOI: 10.1590/1678-4324-2017160226.

[4] Juturu V, Chuan Wu J. Microbial cellulases: Engineering, production and applications. Renew Sust Energy Rev. 2014;33:188-203. DOI: 10.1016/j.rser.2014.01.077.

[5] Horn SJ, Vaaje-Kolstad G, Westereng B, Eijsink VGH. Novel enzymes for the degradation of cellulose. Biotechnol Biofuels. 2012;5:45. DOI: 10.1186/1754-6834-5-45.

[6] Lynd LR, Weimer PJ, van Zyl W, Pretorius IS. Microbial cellulose utilization: Fundamentals and biotechnology. Microbiol Molecular Biol Rev. 2002;66:3:506-77. DOI: 10.1128/MMBR.66.3.506-577.2002.

[7] Shuangqi T, Zhenyu W, Ziluan F, Lili Z, Jichang W. Determination methods of cellulase activity. Afr J Biotech. 2011;10:37:7122-5. DOI: 10.5897/AJB10.2243.

[8] Singhania RR. Cellulolytic Enzymes. Chapter 20. In: Singh P, Pandey A, editors. Biotechnology for Agro-Industrial Residues Utilisation. Utilisation of Agro-Residues. Dordrecht: Springer; 2009; 372-81. ISBN: 9781402099427. DOI: 10.1007/978-1-4020-9942-7_20.

[9] Bayer E, Chanzy, Lamed R, Shoham Y. Cellulose, cellulases and cellulosomes. Curr Opin Struct Biol. 1998;8:548-557. DOI: 10.1016/S0959-440x(98)80143-7.

[10] Kale RA, Zanwar PH. Isolation and screening of cellulolytic fungi. IOSR J Biotech Biochem. 2016;2:6:57-61. Available from: http://www.iosrjournals.org/iosr-jbb/papers/Vol2-issue6/Version2/H0206025761.pdf.

[11] Ordaz-Díaz LA, Rojas-Contreras JA, Flores-Vichi F, Flores-Villegas MY, Álvarez-Álvarez C, Velasco-Vázquez P, et al. Quantification of endoglucanase activity based on carboxymethyl cellulose in four 
fungi isolated from an aerated lagoon in a pulp and paper mill. BioResour. 2016; 11:3:7781-9. DOI: 10.15376/biores.11.3.7781-7789.

[12] Carvalho Dos Santos T, Filho Ga, Riany De Brito A, Pires AJ, Ferreira Bonomo RB, Franco M. Production and characterization of cellulolytic enzymes by Aspergillus niger and Rhizopus sp. by solid state fermentation of prickly pear. Rev Caatinga Mossoró. 2016;29:1:222-33. DOI: 10.1590/1983-21252016v29n126rc

[13] Kadarmoidheen M, Saranraj P, Stella D. Effect of cellulolytic fungi on the degradation of cellulosic

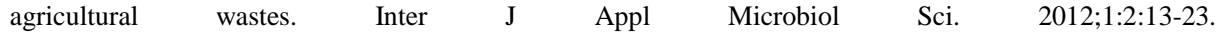
https://www.academia.edu/3878309/Effect_of_cellulolytic_fungi_for_the_degradation_of_cellulosic_agricu ltural_wastes.

[14] El-Hadi AA, Abu El-Nour S, Hammad A, Kamel Z, Anwar M. Optimization of cultural and nutritional conditionsfor carboxymethylcellulase production by Aspergillus hortai. J Radiation Res Appl Sci. 2014;7:1:23-8. DOI: 10.1016/j.jrras.2013.11.003

[15] Kasana RC, Salwan R, Dhar H, Dutt S, Gulati A. A rapid and easy method for the detection of microbial cellulases on agar plates using Gram's iodine. Curr Microbiol. 2008;57:503-7. DOI: 10.1007/s00284-008-9276-8.

[16] Tamada M, Kasai N, Kaetsu I. Estimation of cellulase activity based on glucose productivity. Biotechnol Bioeng. 1988;32:7:920-2. DOI: 10.1002/bit.260320712.

[17] Xiao Z, Storms R, Tsang A. Microplate-based filter paper assay to measure total cellulase activity. Biotechnol Bioeng. 2004:88:7:832-7. DOI: 10.1002/bit.20286.

[18] Dąbkowska K, Mech M, Kopeć K, Pilarek M. Enzymatic activity of some industrially-applied cellulolytic enzyme preparations. Ecol Chem Eng S. 2017:24:1:9-18. DOI: 10.1515/eces-2017-0001.

[19] Lynd LR, Weimer PJ, van Zyl WH, Pretorius IS. Microbial cellulose utilization: fundamentals and biotechnology. Microboil Molec Biol Rev. 2002;66:506-77. DOI: 10.1128/MMBR.66.3.506-577.2002.

[20] Maki M, Leung KT, Qin W. The prospects of cellulose - producing bacteria for the bioconversion of lignocellulosic biomass. Int J Biol Sci. 2009;5:500-16. DOI: 10.7150/ijbs.5.500.

[21] Ariffin H, Abdullah N, Umi Kalsom MS, Shirai Y, Hassan MA. Production and characterization of cellulase by Bacillus pumilus EB3. Int J Eng Technol. 2006;3:1:47-53. http://www.ijet.feiic.org/journals/J-2006V1005.pdf

[22] Lugani Y, Singla R, Sooch BS. Optimization of cellulase production from newly isolated Bacillus sp. Bioprocess Biotech. 2015;5:11:264. DOI: 10.4172/2155-9821.1000264.

[23] Manfredi AP, Pisa1 JH, Valdeón DH, Perotti NI, Martínez MA. Synergistic effect of simple sugars and carboxymethylcellulose on the production of a cellulolytic cocktail from Bacillus sp. AR03 and enzyme activity characterization. Appl Biochem Biotechnol. 2016;179:16-32. DOI: 10.1007/s12010-015-1976-5.

[24] Karim A, Nawaz MA, Aman A, Ali Ul Qader S. Hyper production of cellulose degrading endo $(1,4)$ $\beta$-D-glucanase from Bacillus licheniformis KIBGE-IB2. J Radiation Res Appl Sci. 2014;7:1:23-8. DOI: 10.1016/j.jrras.2013.11.003.

[25] Grata K, Rombel-Bryzek A, Ziembik Z. Bacillus subtilis BS-2 and peppermint oil as biocontrol agents against Botrytis cinerea. Ecol Chem Eng S. 2019;26:3:597-607. DOI: 10.1515/eces-2019-0044.

[26] Liang Y, Zhang Z, Wu M, Wu Y, Feng JX. Isolation, screening and identification of cellulolytic bacteria from natural reserves in the subtropical region of China and optimization of cellulase production by Paenibacillus terrae ME27-1. BioMed Resh Int. 2014;1-13. ID 512497. DOI: 10.1155/2014/512497.

[27] Irfan M, Safdar A, Syed Q, Nadeem M. Isolation and screening of cellulolytic bacteria from soil and optimization of cellulase production and activity. Turk $\mathbf{J}$ Biochem. 2012;37:3:287-93. DOI: 0.5505/tjb.2012.09709.

[28] Poulsen H, Willink FW, Ingvorsen K. Aerobic and anaerobic cellulase production by Cellulomonas uda. Arch Microbiol. 2016;198:725-35. DOI: 10.1007/s00203-016-1230-8.

[29] Berlin A. No arriers to cellulose breakdown. Science. 2013;342:6165;1454-6. DOI: 10.1126/science. 1247697.

[30] Andlar M, Rezic T, Marđetko N, Kracher D, Ludwig R, Santek B. Lignocellulose degradation: An overview of fungi and fungal enzymes involved in lignocellulose degradation. Eng Life Sci. 2018;18:768-78. DOI: 10.1002/elsc. 201800039.

[31] Zhang XZ, Zhang YHP. Cellulases: charecteristics, sources, production, and applications. In: Yang ST, El-Enshasy HA, Thongchual N. Bioprocessing Technologies in Biorefinery for Sustainable Production of Fuels, Chemicals, and Polymers. Hoboken. New Jersey: John Wiley Sons; 2013; 131-46. ISBN: 9780470541951.

[32] Yin LJ, Lin HH, Xiao ZR. Purification and characterization of a cellulase from Bacillus subtilis YI1. J Marine Sci Technol. 2010:18:3:466-71. https://jmst.ntou.edu.tw/marine/18-3/466-471.pdf 
[33] Thapa S, Mishra J, Arora N, Mishra P, Li H, O'Hair J, et al. Microbial cellulolytic enzymes: diversity and biotechnology with reference to lignocellulosic biomass degradation. Rev Environ Sci Biotechnol. 2020;19:621-48. DOI: 10.1007/s11157-020-09536-y.

[34] Orji FA, Dike EN, Lawal AK, Sadiq AO, Suberu Y, Famotemi AC, et al. Properties of Bacillus species cellulase produced using cellulose from brewers spent grain (BSG) as substrate. Adv Biosci Biotechnol. 2016;7:142-8. DOI: 10.4236/abb.2016.73013.

[35] Chantarasiri A. Aquatic Bacillus cereus JD0404 isolated from the muddy sediments of mangrove swamps in Thailand and characterization of its cellulolytic activity. Egyptian J Aquatic Res. 2015;41(3):257-64. DOI: 10.1016/j.ejar.2015.08.003.

[36] Coronado-Ruiz C, Avendaño R, Escudero-Leyva E, Conejo-Barboza G, Chaverri P, Chavarría M. Two new cellulolytic fungal species isolated from a 19th-century art collection. Scientific Reports. 2018;8:7492. DOI: 10.1038/s41598-018-24934-7.

[37] Sunitha VH, Nirmala Dev D, Srinivas C. Extracellular enzymatic activity of endophytic fungal strains isolated from medicinal plants. World J Agri Sci. 2013;9(1):1-9. DOI: 10.5829/idosi.wjas.2013.9.1.72148.

[38] Gohel HR, Contractor CN, Ghosh SK, Braganza VJ. A comparative study of various staining techniques for determination of extra cellular cellulase activity on Carboxymethylcellulose (CMC) agar plates. Int J Curr Microbiol App Sci. 2014;3(5):261-6. https://www.ijcmas.com/vol-35/Hardik\%20R.\%20Gohel,\%20et\%20al.pdf.

[39] Oliveira LRC, Barbosa JB, Martins MLL, Martins MA. Extracellular production of avicelase by the thermophilic soil bacterium Bacillus sp. SMIA-2. Acta Scien. Biol Sci. 2014;36(2);215-22. DOI: 10.4025/actascibiolsci.v36i2.17827.

[40] Kim YK, Lee SC, Cho YY, Oh HJ, Ko YH. Isolation of cellulolytic Bacillus subtilis strains from agricultural environments. ISRN Microbiol. 2012;650563. DOI: 10.5402/2012/650563.

[41] Ferbiyanto A, Rusmana I, Raffiudin R. Charectarization and identification of cellulolytic bacteria from gut of worker Macrotermes gilvus. Hayati J Life Sci. 2015:22(5):197-200. DOI: 10.1016/j.hjb.2015.07.001.

[42] Florencio C, Couri S, Farinas C. Correlation between agar plate screening and solid-state fermentation for the prediction of cellulase production by Trichoderma strains. Enzyme Res. 2012:793708-15. DOI: $10.1155 / 2012 / 793708$.

[43] Ray RR. Microbial avicelase: an overview. Bull Environ Pharmacol Life Sci. 2015;4(4):3-13. http://bepls.com/march_2015/2.pdf.

[44] Miller GL. Use of dinitrosalicylic acid reagent for determination of reducing sugar. Anal Chem. 1959; 31(3):426-8. DOI: 10.1021/ac60147a030.

[45] Ghose TK. Measurement of cellulase activities. Pure Appl Chem. 1987;59(2):257-68. DOI: $10.1351 /$ pac198759020257.

[46] Marsden WL, Gray PP, Nippard GJ, Quinlan MR. Evaluation of the DNS method for analysing lignocellulosic hydrolysates. J Chem Technol Biotechnol. 1982;32:7-12. DOI: 10.1002/jctb.5030320744.

[47] McKee L. Measuring enzyme kinetics of glycoside hydrolases using the 3,5-dinitrosalicylic acid assay. In: Wade Abbott D, Lammerts van Bueren A, editors. Protein-Carbohydrate Interactions. Methods and Protocols. New York, NY: Humana Press; 2017; 27-36. DOI: 10.1007/978-1-4939-6899-2.

[48] Khoshnevisan K, Bordbar AK, Zare D, Davoodi D, Noruzi M, Barkhi M, et al. Immobilization of cellulase enzyme on superparamagnetic nanoparticles and determination of activity and stability. Chem Eng J. 2011;171(2):669-73. DOI: 10.1016/j.cej.2011.04.039.

[49] Yub X, Liua Y, Cuia Y, Chenga Q, Zhanga Z, Lua JH, et al. Measurement of filter paper activities of cellulase with microplate-based assay. J Biol Sci. 2015;44(1):S93-8. DOI: 10.1016/j.sjbs.2015.06.018.

[50] Akhtar N, Sharma A, Deka D, Jawed M, Goyal D, Goyald A. Characterization of cellulase producing Bacillus sp. for effective degradation of leaf litter biomass. Environ Progr Sust Ener. 2012;32(4):1195-201. DOI: 10.1002/ep.11726. 